\title{
An examination of the worked bone and antler assemblage at Uğurlu (Gökçeada, Turkey)
}

\author{
Jarrad W. Paul ${ }^{1}$, Burçin Erdoğu ${ }^{2}$ \\ 1 University of Melbourne, Melbourne, AU \\ jwpaul17@gmail.com \\ 2Trakya Üniversitesi, Edirne, TR \\ burcinerdogu@trakya.edu.tr; berdogu@gmail.com
}

\begin{abstract}
Worked bone and antler tools were regularly used by prehistoric societies in northwest and western Anatolia to create and maintain everyday items. Uğurlu, one of the most important prehistoric sites in the north east Aegean, shows extensive evidence of bone and antler tool manufacture. This article examines the Uğurlu osseous assemblage from its inception during the Early Neolithic (6800 cal BC) to the middle Chalcolithic (4300 cal BC). A typology is established which labels the 534 items uncovered thus far, supported by contextual information. A comparison with other bone tool assemblages in the region is also presented, highlighting group similarities and type differences. The results show that few bone tools were found in the Early Neolithic Phase VI (68006600 cal BC), while pointed tools dominate Phase V (6600-5900 cal BC). The established Neolithic Phase IV (5900-5600 cal BC) witnesses a dramatic growth in the number of bone tools produced, which is steadily adapted with the advent of the Chalcolithic Phase III (5500-4900 cal BC). During this transition between the Neolithic and Chalcolithic, certain tool types decline in number and manufacturing style changes. In the middle Chalcolithic Phase II (4500-4300 cal BC), bone objects seem to be crudely made, possibly reflecting the emergence of local traditions.
\end{abstract}

KEY WORDS - Neolithic-Chalcolithic; bone tools; northwest Anatolia; typology

\section{Pregled zbirov obdelanih kosti in rogov na najdišču Uğurlu (Gökçeada, Turčija)}

IZVLEČEK - Prazgodovinske skupnosti v severozahodni in zahodni Anatoliji so za izdelavo in popravilo vsakdanjih predmetov redno uporabljale obdelana koščena in rožena orodja. Na najdišču Uğurlu, enem najbolj pomembnih prazgodovinskih lokacij na severovzhodu Egejskega prostora, so odkrili številne dokaze o izdelavi koščenih in roženih orodij. V članku preiskujemo koščeni zbir iz Ŭ̆urla od nastanka najdišča v času zgodnjega neolitika (6800 pr. n. št.) do srednjega halkolitika (4300 pr. n. št.). Na podlagi zbira 534 tovrstnih predmetov, ki so bili do sedaj odkriti na najdišču, smo izdelali tipologijo, ki je podprta s podatki o kontekstih. Podatke smo nato primerjali z drugimi kostnimi zbiri v regiji, ki kažejo tako na podobnosti kot na razlike v tipologiji. Rezultati kažejo, da so $v$ času zgodnje neolitske faze VI (6800-6600 pr. n. št.) uporabljali malo koščenih orodij, medtem ko v fazi V (6600-5900 pr.n.št.) prevladujejo konice. Vobdobju uveljavljenega neolitika v fazi IV (59005600 pr.n.št.) se je število obdelanih koščenih orodij dramatično povečalo, ki se postopoma prilagodi v začetku halkolitika v fazi III (5500-4900 pr. n. št.). Prisotnost določenih tipov orodij se zmanj$\check{s}$ a v času prehoda med neolitikom in halkolitikom, spremeni pa se tudi stil izdelave. V času srednjega halkolitika v fazi II (4500-4300 pr. n. št.) so koščena orodja grobo izdelana, kar morda kaže na pojav lokalnih tradicij pri izdelavi.

KLJUČNE BESEDE - neolitik-halkolitik; koščena orodja; severozahodna Anatolija; tipologija 


\section{Introduction}

Animal bone was an important raw material source at Uğurlu, as its durability and manageability was utilised to create strong and versatile items. The systematic study of worked bone tools had its inception in the mid-20th century. Focus on typologies quickly expanded into other related areas, including use-wear analysis and experimental replication studies (for early concepts of bone tool typologies, see Camps-Fabrer 1966.82-135; Schibler 1980; for usewear analysis, see Semenov 1964; LeMoine 1997; for replication studies, see D'Errico et al. 1984; Goodarzi-Tabrizi 1999). In recent years, significant scientific advances have been made regarding the study of bone tools, expanding the knowledge base for this discipline (Bradfield 2015.3-14; Spangenberg et al. 2014.11-25; Griffitts 2011.52-66; Choyke 2007. 641-665; Legrand, Sidéra 2007.67-80). In Anatolia and the Balkans, prehistoric bone tool studies now largely integrate typological analysis with an emphasis on scientific and theoretical procedure (Russell 2005.339-369; Dekker 2014; Vitezović 2011.117136; Zidarov 2008.57-62).

Specialised publications of bone tools from Neolithic northwest Anatolia are lacking, with many site reports incorporating this material group with other small finds. A number of sites (Așağ 1 Pinar and Barcin Höyük in particular) (Erdalkıran 2017.235 vd; Azeri 2015; Dekker 2014) have specialists currently working on their worked bone material, while indepth analysis from non-worked bone experts is included in the reports from Yeşilova, Yenikap1, Hoca Ceşme, Fikirtepe, and Pendik (Derin 2012.182; Kızltan, Polat 2013.123; Özdoğan 2001.33-34; 2013. 174-182). Furthermore, the prehistoric sites of Yarimburgaz Cave, Toptepe, Aktopraklık, Ege Gübre, and Ulucak contain limited amounts of worked bone information in their published reports (Özdoğan 2001.8-11, 64-66; Karul, Avcı 2011.1-15; Sağlamtimur 2012.197-225; Çevik 2012.143-158; Cilingiroğlu et al. 2004.50). However, there are some examples of detailed worked bone investigation, such as Marinelli's report on the Ilipinar bone and antler assemblage (Marinelli 1995.122-143).

Excavators at Neolithic sites in modern-day Greece and Bulgaria pay close attention to worked osseous material. Rosalie Christidou and Michel Séfériadés examined the Neolithic assemblages at Limenaria and Dikili Tash to emphasise aspects of bone exploitation in the region (Christidou 2005.91-104; Séfériadés 1992.99-112. The term Neolithic used for sites in Greece corresponds with the Anatolian Chalcolithic period). Peter Höglinger's (1997.157-196) detailed report on the 272 stratified bone objects discovered at Karanovo is a notable addition to Bulgarian worked bone tool studies. Site reports from Yabalkovo and Kovačevo also contain further information for this region (Leshtakov et al. 2007.185-234; Sidéra 2013.173-178; Lichardus Itten et al. 2006. 83-94).

Positioned in the north Aegean off the northwest coast of Anatolia, Uğurlu, on the island of Gökçeada, is one of the earliest sites with evidence of farming and animal husbandry in the Aegean. Stratigraphic excavations have clarified the spatial extent of the settlement from the pre-pottery Neolithic occupation (c. $6800 \mathrm{cal} \mathrm{BC}$ ) and brought to light evidence of the earliest examples of pottery production (c. 6600/ $6500 \mathrm{cal} \mathrm{BC}$ ). A clear, yet gradual transition from the Neolithic to the Chalcolithic period is also observable (c. $5500 \mathrm{cal} \mathrm{BC})$. Bone and antler tools were frequently created and used by this community to support their burgeoning lifestyle. This paper explores the bone tool assemblage with a focus on a typological and contextual analysis of the material. The subsequent discussion will provide an initial assessment of these tools and their position within the wider region.

\section{The Uğurlu excavation}

Uğurlu is located on the western part of Gökçeada (Fig. 1). The site is a low mound covering an area of approx. $250 \times 200 \mathrm{~m}$ on a gentle slope at the eastern foot of Mount Isa (Doğanlı). The main Uğurlu-Dereköy road cuts through the site. So far, during the eight years of excavation, six main cultural phases, designated as I-VI (counting from top to bottom), and at least 15 layers of occupation have been revealed. The earliest Phase VI dates to the pre-pottery Neolithic period, c. $6800-6600$ cal BC. Phase $\mathrm{V}$ is marked by the first pottery Neolithic, $c$. 6600/65005900 cal BC. During Phase IV, around 5900/5800 cal BC, the settlement expanded, and the islanders may have formed their own culture and identity. Around $5500 \mathrm{cal} \mathrm{BC}$, major changes occurred at Uğurlu. These variations occurred in all aspects of cultural life, as indicated by modifications in settlement pattern, spatial organisation, the plan of buildings, art, and pottery production. The spatial organisation of settlements and building plans were further modified around 4500-4300 cal BC (Erdoğu 2014.157-178; 2016.89-94). 


\section{Worked bone and antler assemblage}

\section{Methodology}

A ten-stage procedure was designed to collect information. After recording contextual information, the raw material (bone, antler, or tooth) of the object was recorded. The tool was then placed within a group, type, and if needed, sub-type. The object was measured (including maximum length, width, and thickness) and described. In this regard, each object was divided into a base, shaft, and tip and described individually. Surface condition, colour, and modification (in the form of striation direction) were then recorded. Striations were identified with the naked eye, a 33 magnification eye-piece, and in some cases, a USB microscope with $\times 200 \mathrm{zoom}$. This microscope has a dual axis $\times 50$ and $x 200$ lens with a manual focal range of $10 \mathrm{~mm}$ onwards. The taxonomy and element were also recorded, limited to broad categories of small, medium, and large animal bones that were either long, short, flat, or irregular. All items were photographed and illustrated, with data recorded in a searchable database.

\section{Typology}

In total, 534 worked antler and bone items have been recorded thus far (Tab. 1). From these, 455 have been typed, while the remaining 79 have been classified as undefined. Objects identified as undefined are either too fragmented to classify or have no formal shape. Some are waste from manufacture. In order to create a more distinct picture of the assemblage, any data using percentages relates to the 455 typed objects only.

The typology is first separated into four groups: 'pointed tools', 'cutting tools', 'polishing tools', and 'other'.

The most prominent type in the pointed tool group are points (Fig. 2). This type is used to describe any worked object with a pointed tip, excluding needles or pins. They were employed for a variety of tasks relating to perforation. The creation of everyday items such as clothes and shoes would have required the use of points to create stitching holes. Points were also required in ceramic decoration and textile manufacture to ma- nipulate the visual form of an item. The decision to label this type 'point' rather than 'awl' is based on the unique functional characteristics of awls. Awls have a specific morphological function, and thus labelling all points as awls is misleading. Due to the large quantity of points ( $\mathrm{n}=191,42 \%$ of the overall assemblage) eight sub-types have been defined, divided by morphology, raw material selection, and additional decoration (Tab. 2).

Type A points are most common, with 115 examples, and are characterised by a break on the shaft with a pointed proximal and no epiphysis or base. Type B consists of a longitudinally split bone with an intact distal end, while type $C$ are split lengthwise, with the base or distal end split in half. Type D points have a rounded and smoothed distal epiphysis, and type $\mathrm{E}$ are identified by an angled proximal caused by abrasion on one lateral. Type $\mathrm{F}$ points are defined by decorations or additions made to the object's surface. Two motifs are apparent: one is a zigzag pattern seen on two examples, while another has a double-'v' incision (Fig. 3). Type G has a flattened and wide shaft that narrows into a small rounded tip, and what I describe as an awl, while type $\mathrm{H}$ comprises pointed objects made on other elements beside metapodial or tibia bones. Due to the variety of type $\mathrm{H}$ bone elements, mean length, width, and thickness varies greatly (the largest being a $88.42 \mathrm{~mm}$ tool crafted from a femur and the smallest being a $39.78 \mathrm{~mm}$ tool constructed from an incisor). Types A through $\mathrm{G}$ are mainly made on medium sized animal long bones, mostly metapodial bones of sheep and goats. Parallels exist between regional and inter-regional point types (Tab. 3).

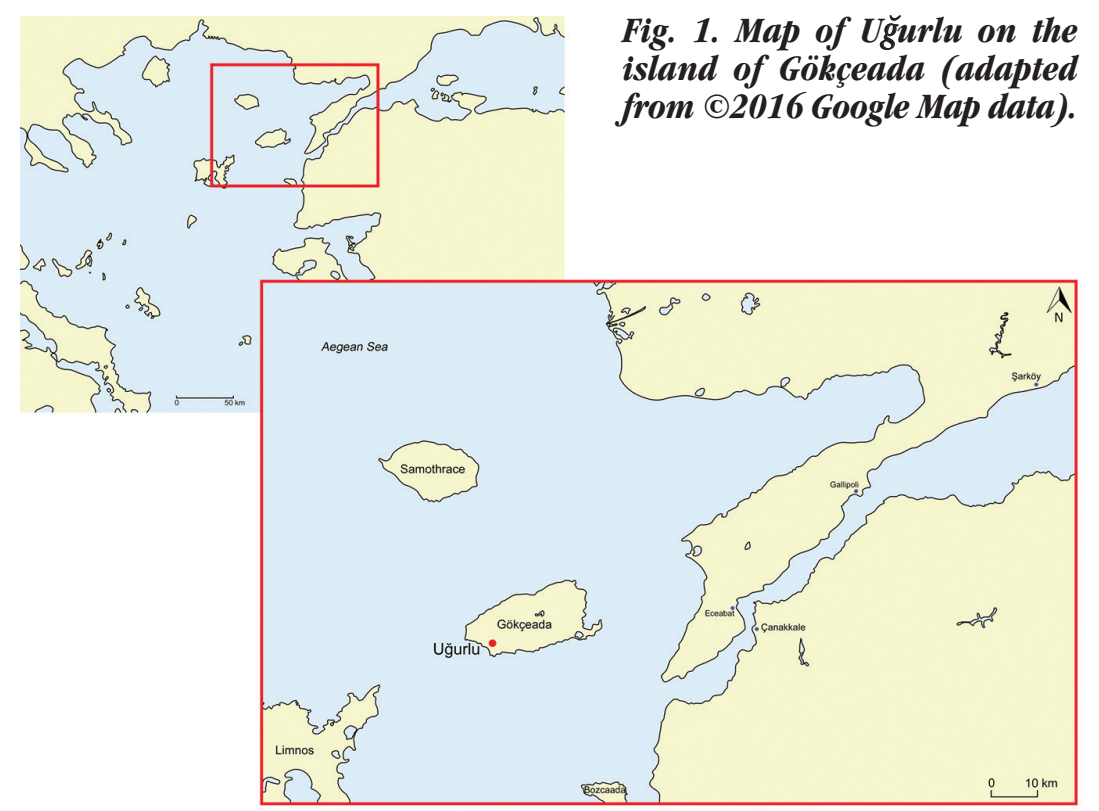




\begin{tabular}{|c|c|c|c|c|}
\hline Group & Type & Sub-type & Number & Total \\
\hline \multirow{16}{*}{$\begin{array}{l}\text { Pointed } \\
\text { tools }\end{array}$} & \multirow[t]{8}{*}{ point } & Type A & 115 & \\
\hline & & Type B & 11 & \\
\hline & & Type C & 12 & \\
\hline & & Type D & 27 & \\
\hline & & Type E & 13 & \\
\hline & & Type F & 3 & \\
\hline & & Type G & 5 & \\
\hline & & Type H & 5 & 191 \\
\hline & \multirow[t]{2}{*}{ rounded point } & Type A (bone) & 17 & \\
\hline & & Type B (antler) & 14 & 31 \\
\hline & \multirow{2}{*}{$\begin{array}{l}\text { bi-point } \\
\text { hook }\end{array}$} & & 2 & 2 \\
\hline & & & 6 & 6 \\
\hline & needle & Type A (notched) & 20 & \\
\hline & & Type B (perforated) & 3 & 23 \\
\hline & \multirow[t]{2}{*}{ pin } & Type A (pin) & 43 & \\
\hline & & Type B (pin-point) & 4 & 47 \\
\hline \multirow{4}{*}{$\begin{array}{l}\text { Cutting } \\
\text { tools }\end{array}$} & chisel & & 4 & 4 \\
\hline & gouge & & 8 & 8 \\
\hline & pick & & 1 & 1 \\
\hline & puncher & & 1 & 1 \\
\hline \multirow{4}{*}{$\begin{array}{l}\text { Polishing } \\
\text { tools }\end{array}$} & \multirow{4}{*}{$\begin{array}{l}\text { smoother } \\
\text { spatula }\end{array}$} & Type A & 83 & \\
\hline & & Type B & 8 & 91 \\
\hline & & Type A & 23 & \\
\hline & & Type B & 7 & 30 \\
\hline \multirow{6}{*}{ Other } & \multirow{6}{*}{$\begin{array}{l}\text { component/ } \\
\text { composite elements } \\
\text { perforated object } \\
\text { preform } \\
\text { utensil }\end{array}$} & Type A - handle & 4 & \\
\hline & & Type B - shaft & 6 & 10 \\
\hline & & & 2 & 2 \\
\hline & & & 4 & 4 \\
\hline & & Type A - spoon & 2 & \\
\hline & & Type B - spatula-spoon & 2 & 4 \\
\hline Total & & & 455 & 455 \\
\hline Undefined & & & 79 & 79 \\
\hline Total & & & 534 & 534 \\
\hline
\end{tabular}

Tab. 1. Uğurlu worked bone and antler typology.

There are five other types in the pointed tool group (Fig. 4). Rounded points are distinguished from points by having rounded and blunt tips. They are divided according to their raw material, with type $\mathrm{A}$ made from bone, while type $B$ are made from antler.

Only two bi-points are recorded, and are described as having both a pointed tip and base. This tool is associated with textile production or fishing related activities. Regarding fishing, three fish hooks are present. They vary in size and form, with breakage normally occurring on the bend, where the greatest amount of force is exerted. Two decorated headed bone hooks are also noteworthy. They were possibly used for securing clothing.

Needles are well represented and defined by a pointed tip either incised on the distal lateral (type A) or perforated at the base (type B). Of particular importance was the discovery of a large number of type A needles in trench $\mathrm{P} 5$, unit B91, discovered inside a pit and dated to $5600 \mathrm{cal} \mathrm{BC}$. Considering their apparent deliberate placement, and no obvious parallels in the wider region, these objects may have had significant cultural value for the inhabitants of Uğurlu (Fig. 5).

The final type in the pointed tools group is pins. They are the second most frequent pointed tool and are circular, with a slender shaft and pointed tip. The majority fit into this form (type A); however, some (type B) have a non-circular shaft, but are slender and thin. Based on striation direction, these tools are related to perforation activities.

The second tool group are cutting tools, which comprises four types (Fig. 6). The tools in this group are associated with activities that require cutting, scraping or striking. There are 14 cutting tools in total, making this the smallest group (3\% of the overall collection). Chisels are defined by a bevelled tip and compact shaft, with no set base profile. Use-wear analysis from Çatalhöyük suggests these types of tools were used for woodworking activities (Giffitts 2011.52-66). Gouges have a hollowed shaft, varied degrees of base modification and a modified tip. Tips were most commonly strengthened by burning until blackened. This reinforces the bone cortex, making it easier to use on hard materials. A pick and a punch, both made from antler, were also found. The pick may have been used for digging, while the punch was used by striking the base with another tool, transferring the energy to the tip to exert force. After continual use, the base and tip are left damaged, exposing the spongy bone.

There are only two types in the polishing tool group; however, it is the second most frequent group ( $\mathrm{n}=$ $123,27 \%$ of the overall assemblage). These tools are associated with the removal of excess material dur- 


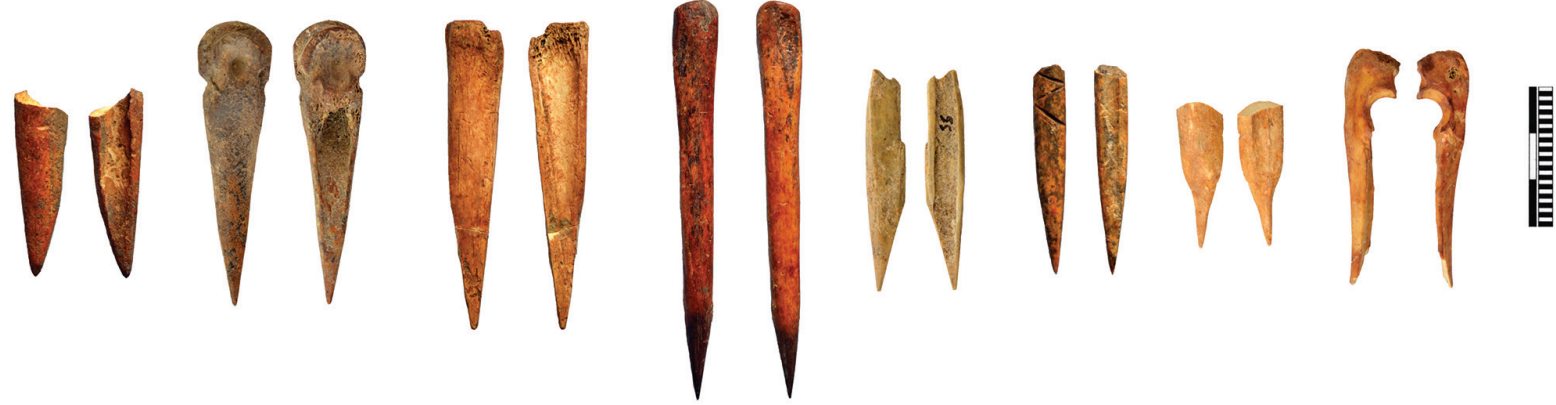

Fig. 2. Uğurlu points. Left to right: type A (CC21B26x1); type B (P5B148x4); type C (DD20B4x1); type D (P6B7x9); type E (P5B106xz2); type F (BB20-21B9x1); type G (QP6B6x4); type H (BB20-21B59x7) (designed by J. W. Paul).

ing hide preparation and pottery moulding (Fig. 7). The first of these are smoothers. Smoothers are also referred to in the Turkish literature as mablak. Some authors label morphologically similar items as chisels or gouges. They are characterised by a long curved shaft, either open (type A) or flat (type B), with a bevelled tip and base worked to varying degrees. Type A smoothers outnumber type B and are made from long bones, including metapodial, radius, and tibia bones, of medium- and large-sized animals. Striations usually appear on the second aspect of these objects, running horizontally and diagonally.

The second type in this group is spatulas. A spatula has a flat, broad shaft with elongated ends and is made exclusively on rib bones split lengthwise. Type $A$ and $B$ are differentiated by tip morphology: type $A$ is rounded, while type B is pointed. Their primary purpose was pottery moulding. Closely linked with pottery production, experimental studies show that they are extremely useful in regularising the shape of ceramics and removing excess material (Mărgărit 2017.206).

Items in the 'other' tool group are not functionally associated with pointing, cutting, or polishing activities. This includes artefacts that appear not to be tools but, rather, to be worked bone and antler objects that may fulfil a variety of other functions, including use in ritual settings or as items with purely aesthetic value. There are 20 items in this group, divided into five types and four sub-types (Fig. 8).

Component/composite elements are separated into handles (type A) and shafts (type B). Handles

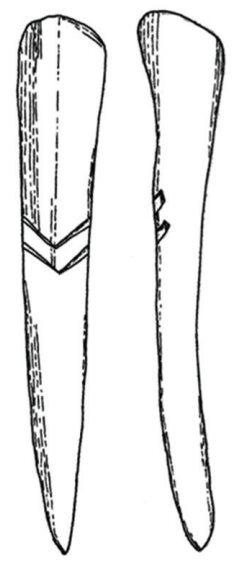

in this context refers to handles for spoons, where the bowl has been broken off, while shafts are made exclusively from deer antler and hollowed out at one end to hold a sharp stone object. Shafts acted as handles to protect the user's hands, resulting in the ability to exert greater force.

Two perforated objects are included in this group. The first was made of deer antler and was perforated in the middle of the shaft, while the other is rectilinear, with a rounded and smoothed base. I suggest the latter perforated object may have functioned as a toggle used to hold a garment together, as it is similar in appearance to modern examples.

Four preforms are also recorded. A preform is any object displaying early signs of manufacture, but never made into a complete type. It is important to record them, as they can highlight procedural steps taken in constructing certain types. For example, one object is a needle preform which has the beginning of a perforation on one aspect and a dimpled impression on the other. Much of this object is rough, suggesting drilling was an initial step in the manufacturing process.
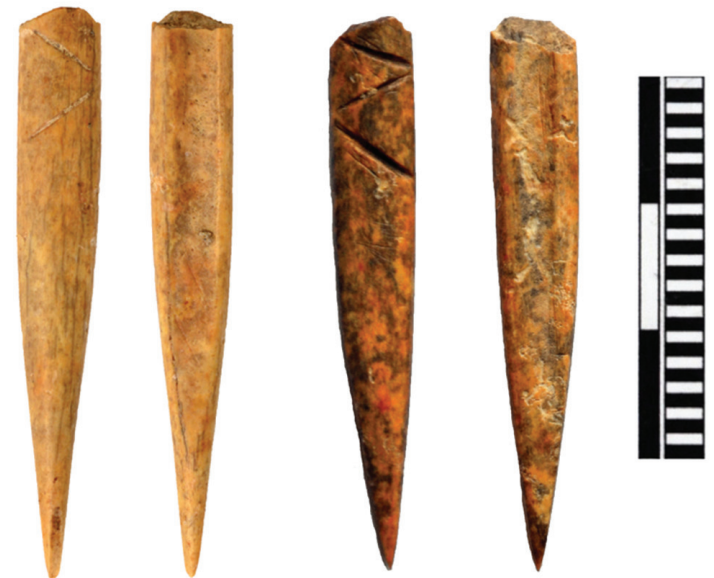

Fig. 3. Point type F: P5B87x5, P6B41x2, BB20-21B9x1 (designed by B. Erdoğu and J. W. Paul). 


\begin{tabular}{|l|c|c|c|c|c|c|c|c|c|c|}
\hline Sub-type & \multicolumn{10}{|c|}{ Phase } \\
\hline & $\mathrm{VI}$ & $\mathrm{V}$ & $\mathrm{V}-\mathrm{IV}$ & $\mathrm{IV}$ & $\mathrm{IV}-\mathrm{III}$ & $\mathrm{III}$ & $\mathrm{II}$ & surface & unknown & Total \\
\hline $\mathrm{A}$ & 1 & 4 & 5 & 37 & 5 & 42 & 8 & 5 & 8 & 115 \\
\hline $\mathrm{B}$ & - & 1 & 1 & 6 & 1 & 2 & - & - & - & 11 \\
\hline $\mathrm{C}$ & - & 2 & 1 & 4 & 1 & 3 & - & - & 1 & 12 \\
\hline $\mathrm{D}$ & - & 4 & - & 7 & - & 10 & 1 & 2 & 3 & 27 \\
\hline $\mathrm{E}$ & - & - & - & 5 & - & 4 & 3 & - & 1 & 13 \\
\hline $\mathrm{F}$ & - & - & 1 & 2 & - & - & - & - & - & 3 \\
\hline $\mathrm{G}$ & - & - & 1 & 2 & 1 & - & 1 & - & - & 5 \\
\hline $\mathrm{H}$ & - & - & 2 & - & 1 & 2 & - & - & - & 5 \\
\hline Total & 1 & 11 & 11 & 63 & 9 & 63 & 13 & 7 & 13 & 191 \\
\hline
\end{tabular}

\begin{tabular}{|c|c|c|c|c|c|c|}
\hline 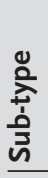 & 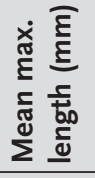 & 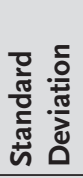 & 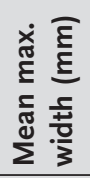 & 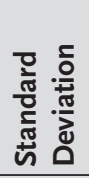 & 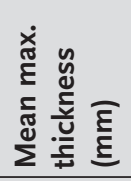 & 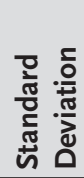 \\
\hline$A$ & 45.8 & 15.3 & 8.0 & 3.1 & 2.5 & 0.9 \\
\hline$B$ & 59.4 & 18.9 & 12.0 & 3.2 & 2.7 & 1.6 \\
\hline $\bar{C}$ & 60.7 & 14.4 & 12.3 & 3.5 & 2.9 & 1.7 \\
\hline $\bar{D}$ & 60.9 & 19.2 & 8.6 & 3.2 & 2.9 & 0.8 \\
\hline $\mathrm{E}$ & 50.2 & 18.2 & 8.5 & 2.5 & 2.8 & 1.1 \\
\hline $\mathrm{F}$ & 44.5 & 0.6 & 6.8 & 0.4 & 2.1 & 0.6 \\
\hline $\mathrm{G}$ & 35.0 & 10.0 & 8.9 & 0.2 & 2.0 & 0.9 \\
\hline$\overline{\mathrm{H}}$ & - & - & - & - & - & - \\
\hline
\end{tabular}

Tab. 2. Uğurlu points sub-type contextual distribution, measurements, and parallel types.

Utensils complete this group. Type A are described as spoons, with a rounded and bowled-shaped tip and handle, or broken shaft where the handle would have been. These items are associated with dairying activities, scraping, or ritual/symbolic settings. When slanting occurs on the bowl, as with sample DD20$\mathrm{B} 8 \mathrm{x} 1$, repeated scraping actions are implied. Type B are labelled spatula-spoons. Like type A, they have a concave head and handle, but the shaft is elongated and the head is wider.

The remaining 79 objects are labelled 'undefined' (Fig. 9). Some items in this group have clearly been modified, but their function remains unknown. Modifications involve notches, cut marks, and striation patterns. In addition, some objects are tools, but their function remains unknown. For example, three objects all share the same morphology and are manufactured on large animal long bones. It has been suggested that they may have acted as fishing rods. Another object from Phase II, $c .4300$ cal BC is shaped much the same as a pipe, but there is no hollow connection between the stem and bowl. It may have been used as a digging instrument. There is also a collection of smoothed objects that are too small to be formally identified.

\section{Context}

Important contextual levels relating to the worked bone and antler collection will be outlined in the following section. Not limited to the worked osseous
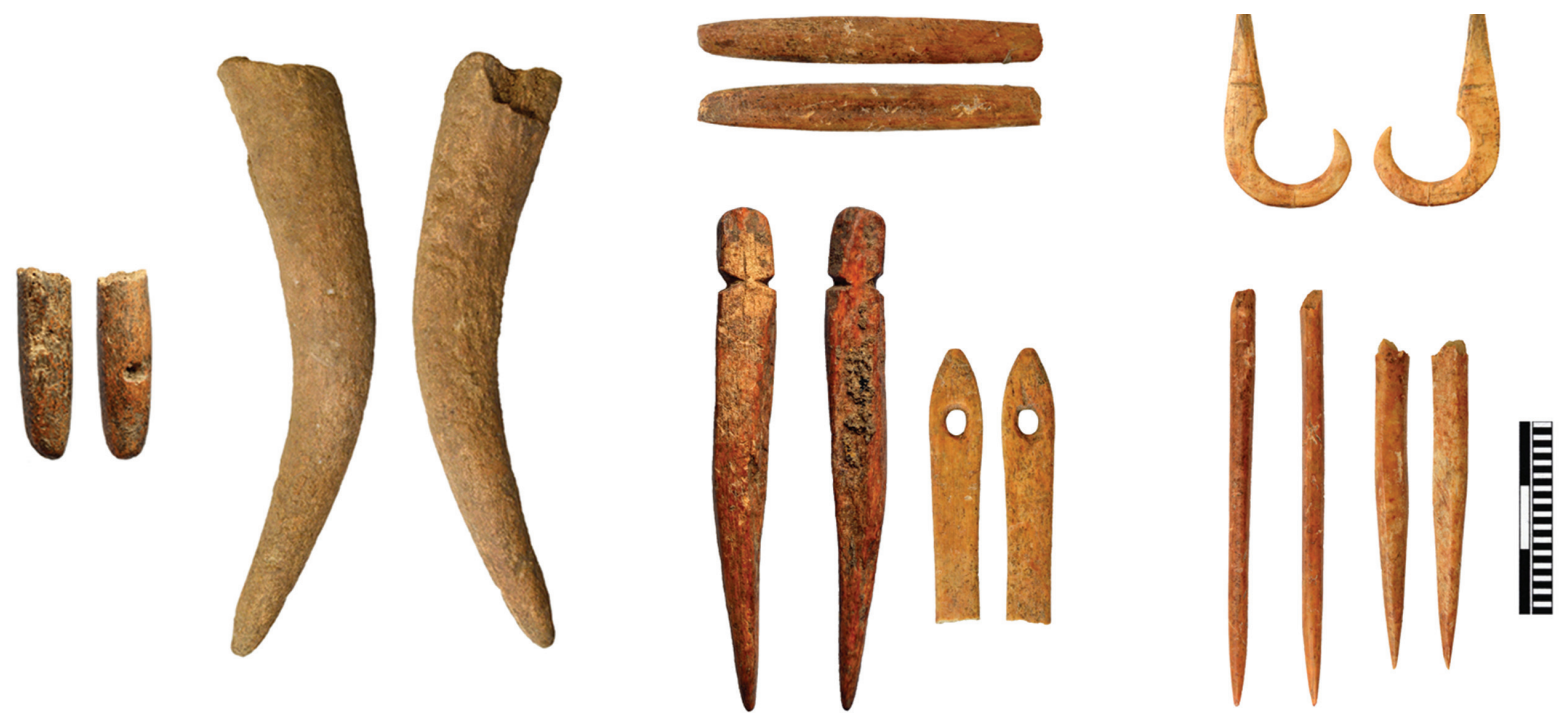

Fig. 4. Uğurlu pointed tools. Left to right: rounded point type A (BB22B10x2); rounded point type B (P6ppx2); bi-point (P6B33x5); fish hook (BB20-21B59x6); needle type A (05B18x1); needle type B (05B36x3); pin type A (P6B25x3); pin type B (P6B30x6) (designed by J. W. Paul). 


\begin{tabular}{|lll|}
\hline Sub-type & Regional Parallels & Inter-Regional Parallels \\
\hline $\mathrm{A}$ & Ulucak Höyük point type A & Tóth's type 1/7-1/9; Camps-Fabrer point type IV; Makri type 1.1b \\
\hline B & Ulucak Höyük point type B & Camps-Fabrer type II; Schibler's type 1/1; Choyke no. 1; \\
& Ilıpınar awl type A & $\begin{array}{l}\text { Payne type 2, type 3; Dikili Tash type IIIB, VIIA; Cave of Cyclops type B; } \\
\text { Karanovo point/awl type A }\end{array}$ \\
\hline $\mathrm{C}$ & Ulucak Höyük point type C & Camps-Fabrer type III; Schibler type 1/2; Chomko type II; \\
& Ilıpınar awl type B & Dikili Tash type IVB, VIIA; Karanovo point/awl type B \\
\hline D & Ulucak Höyük point type D & Camps-Fabrer Type V \\
\hline E & Ilıpınar awl type B & \\
\hline Ulucak Höyük point type E & Dikili Tash type VIIB; Karanovo type C \\
\hline H & Ulucak Höyük point type G & Camps-Fabrer type IVa \\
\hline
\end{tabular}

\section{Tab. 3. Regional and inter-regional parallels for point sub-types.}

material, this investigation will take into account relationality with other items in the overall material record. This section is divided into chronological phases, beginning with the earliest, to highlight developmental change in the assemblage.

\section{Phase VI (Pre-Pottery Neolithic 6800-6600 cal BC)}

The earliest occupation at Uğurlu is represented in two deep trenches in the eastern part of the settlement, namely BB20-21 and CC21. Five bone tools have been recovered so far, comprising three spatulas, one spatula-spoon, and one type A point.

Phase V (Early Neolithic 6600-5900 cal BC) The worked bone objects in Phase V can be described as skilfully constructed, extensively used, and de- posited largely intact. Twenty-three objects have been recorded so far and are confined to the eastern side of the site in trenches BB20-21 and BB22. The majority of these items are pointed tools, with points $(\mathrm{n}=11)$ common. Sub-typed points range from A-D, with type A $(\mathrm{n}=4)$ and type $\mathrm{D}(\mathrm{n}=4)$ predominating. Overall, points were modified to a great extent, as shown by finer measurements, surface condition, and overall preservation. Only one object is made from antler, while the rest are made from bone. The early inhabitants of the site had limited access to this material and, considering the distance to the mainland, access to deer, and therefore antler, would have been restricted, with sheep and goat favoured on the island for size and adaptability. Unit B58 in trench BB20-21 contained the most bone tools (three points, a smoother, and an undefined
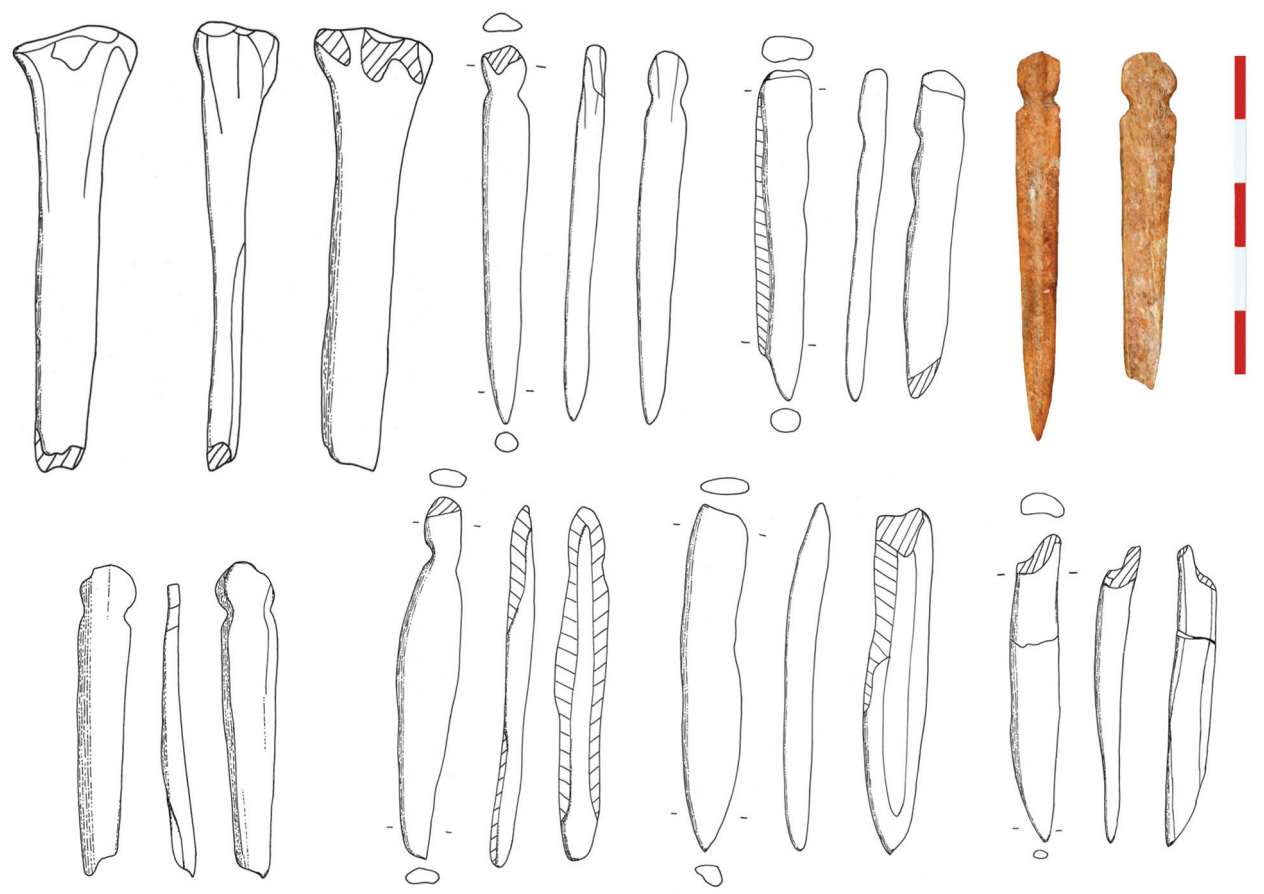

Fig. 5. Worked bone assemblage in 'box-like pit' from trench P5, unit B91: P5B91x2, x3, x6, x9, x10, x13, x14 (designed by B. Erdoğu, N. Yücel and J. W. Paul). 
item) with worked sea shell and stone also recorded. The proximity of these items with stone and sea shell objects suggests an early connection between material groups. Relatively low numbers of finds in this period may be a result of two major factors. The first is access to raw material during an initial settlement process, and the second is the constricted excavation area. The shift from the Early Neolithic Phase V into the established Neolithic Phase IV (5900 cal BC) again sees pointed objects dominate, with points the most frequently recorded $(\mathrm{n}=11)$, while polishing tools are also well represented (smoothers $n=3$; spatulas $n=4$ ). Only one object was not undefined, reflecting a general trend in the assemblage towards formality of types.

\section{Phase IV (Late Neolithic 5900-5600 cal BC)}

Phase IV at Uğurlu saw an expansion of material culture and architectural remains spread towards the western part of the site. Trenches 05, 06, P5, and P6 all contained vast amounts of worked bone material, more than was found on the eastern part of the site. 161 tools in this phase make it the second largest. Again pointed tools dominate, with points the item recorded most often $(n=63)$. A definite trend is now emerging, with type A points comprising the majority $(n=37)$. The zigzag motif carries into this period, as seen on one object. Another motif also appears at this time, a double ' $v$ 'shaped incision on the middle of the shaft of one item, discovered in a fill level with four other worked bone objects. This complete object dates to Phase IV level 1, 5900-5800 cal. BC. These incisions seem to have served no functional purpose; rather, they have been added for purely artistic effect. Additional time is required when incising an object for purely decorative reasons, accounting for the relatively low number of decorated points in the overall assemblage $(n=3)$. After this period, no further decorated points are found in the assemblage. Thus, Phase IV represents a peak in the production of decorated pointed objects.

Pins $(\mathrm{n}=18)$ are numerous in the Neolithic, with their slender shafts displaying high levels of polish. Needles $(n=12)$ are also well represented and their numbers peak during this phase. Cutting tools also reach their peak during Phase IV, with chisels $(\mathrm{n}=3)$ and gouges $(\mathrm{n}=$

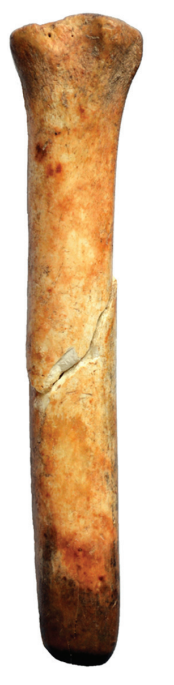

3) represented, while polishing tools also becoming more frequent, with smoothers $(n=29)$ the second most frequent type. Spoons and spatula-spoons reach their highest numbers during this period. Flatter and wider spatula-spoons are larger in size, while object DD20B8x1 (Fig. 10) shares characteristics with similar regional examples.

Large amounts of worked bone and antler material from this period are spread across a variety of contexts. Only a few worked bone objects from the Late Neolithic originate from known contexts. On the eastern side, sixteen artefacts were discovered on floor unit B24 in trench BB20-21, 11 of which were worked bone. The remaining objects included two polished stone axes and one bead.

Besides floor levels, worked bone was also found in pits during the Neolithic. Unit B91 in trench P5 is a pit which contained 14 bone tool objects enclosed with yellow-coloured plaster. Many of the tools inside were type A needles. Interpreted as idols (Erdo$\breve{g u} 2014.159$ ), these symbolically charged objects can be seen to represent an anthropomorphic form, with their notched bases representing a head, possibly inserted into clay figurines.

Fill deposits in trench P5 (units B14, B108, B104) also contained numerous bone tools alongside other objects, including worked sea shell, worked stone, and figurines. In all instances, breakage is an appropriate reason for the discard of these items. The transition from Neolithic to Chalcolithic $(5500 \mathrm{cal}$ $\mathrm{BC}$ ) was moderate when observing the distribution
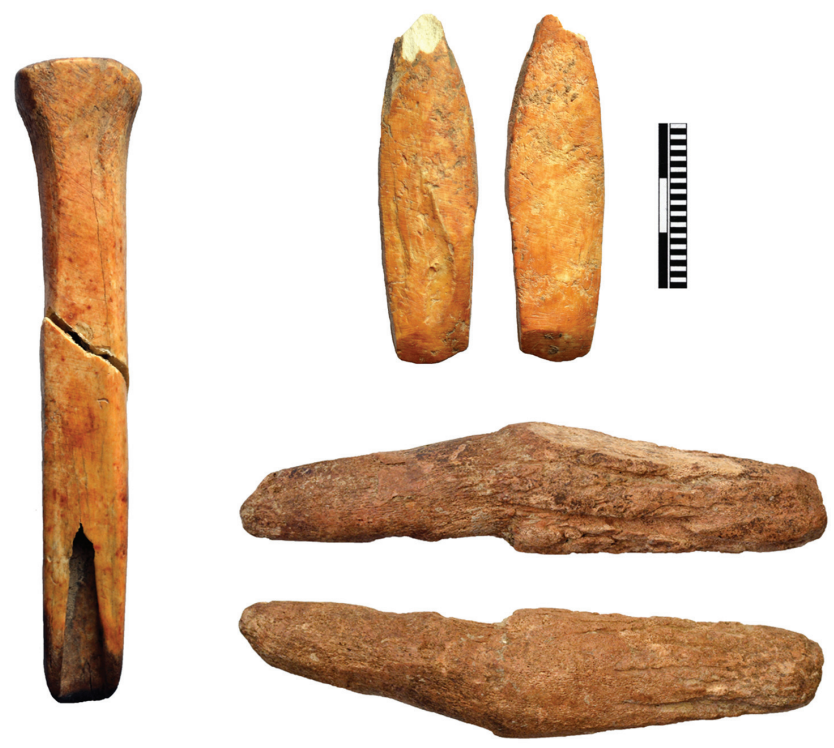

Fig. 6. Uğurlu cutting tools. Left to right: gouge (P5B98x7); chisel (CC21 B19x4); punch (P6ppx3) (designed by J. W. Paul). 
of bone tool types, although in some cases, initial shifts in type frequencies become fully recognisable during the subsequent phase.

\section{Phase III (Early Chalcolithic 5500-4900 cal BC)}

The Chalcolithic period at Uğurlu is defined by maximum settlement growth and a variation in material culture. The worked bone reflects broad patterns of change, with new tool types favoured. It would be wrong to suggest that the quality of these items declined. Instead, a clear move towards homogeneity in some tool types of tools is noticeable, indicating shifts in manufacturing practice. A total of 176 worked bone objects from this period have been found, with pointed tools predominating $(n=63)$. The demise of types $F$ and $G$, coupled with the inflated prevalence of type A points $(n=42)$, shows a move towards regularity in the point type. Additionally, pin and needle distribution all favour one sub-type of the other (type A pin: $n=20$, type $B$ pin: $n=0$; type A needle: $n=6$, type $B$ needle: $n=0$ ). Type A needles decline in frequency $(n=6)$, an interesting observation given their potential symbolic meaning. Perhaps their production became so regularised they were manufactured on materials easier to procure (but degradable), such as wood. Cutting tools are relatively uncommon, consistent with previous periods, while the number of smoothers remains the same $(n=23)$; however, they also become more homogenised, with only one type $\mathrm{B}$ recorded. The three component/composite elements are all type B shafts made from deer antler, while type B rounded points (made from deer antler) also increase during this period $(n=5)$. The more frequent use of this material might be linked to enhanced access to deer. Spoons and spoon handles also decline in number, with only one example recorded. This object, a small circular spoon head, with a missing long thin handle, is reminiscent of the spoons at Pendik and Kovačevo. Only one perforated object was found from this period. This item has one complete hole and one fragmented hole drilled from both sides, and possibly functioned as a toggle.

Floor levels offer the best contextual evidence. Trench V18 yielded four floor levels containing worked bone

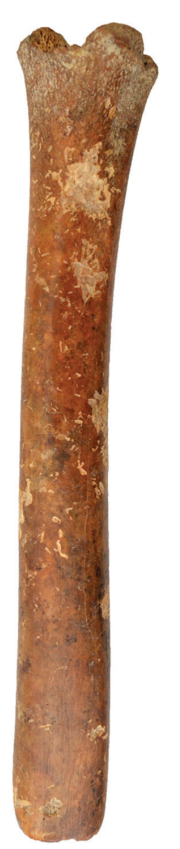

and antler material. Unit B12 contained two worked bone items and a piece of worked stone, while unit B11 yielded one worked bone pointed tool and one worked stone example. Interestingly, only one worked stone object was found in each of the two units, a trend with floor levels found in this trench.

Fill contexts contain the most worked bone material in trenches on both sides of the site. Trench DD19-20, unit B2, is located inside Building 3 and included two type A pins, one stone chisel, and one worked sea shell. The pins are parallel in size, form, and colouration. They are well worn, with notches and scrapes covering their surfaces, and were uncovered next to one another. Unit B4 in trench BB22 produced some interesting results, with four spatulas found together: two type A and two type B. These objects, used for shaping the interior and exterior of pottery, were found within a dense concentration of animal bones. With only one type of bone object worked bone spatulas - uncovered in this unit, it is safe to assume the area was associated with ceramic production. In the west, trenches $\mathrm{P} 5$ and $\mathrm{P} 6$ also contain numerous worked bone examples from fill contexts, especially unit B60 in trench $\mathrm{P} 5$. This has been labelled a pit, with a vast amount $(n=18)$ of bone tools damaged by burning. For example, one expertly crafted type A needle with two layers of notching at the base appears blackened because of burning.
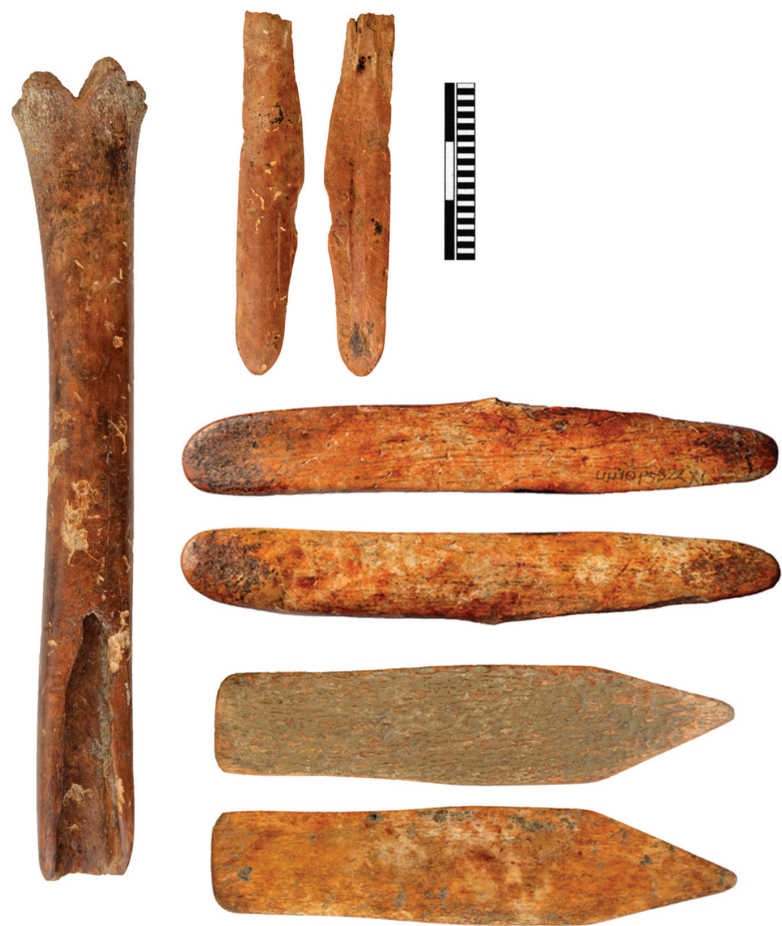

Fig. 7. Uğurlu polishing tools. Left to right: smoother type A (P6B40x1); smoother type B (P5B137x6); spatula type A (P5B22x1); spatula type B (P5B148x2) (photo by J. W. Paul). 
Due to the symbolic nature of type A needles, the destruction of such a finely crafted object suggests it was unintentional. However, its placement within a pit may suggest that this object was in fact intentionally burnt. Perhaps this may have been a part of the ritual surrounding them, which explains their absence in the material record past the Neolithic period.

Overall, the worked bone assemblage of Phase III marks a period of adaptation. There is maximisation of homogenous forms, increase in the use items made from antler (Phase V: $\mathrm{n}=1$; Phase IV: $\mathrm{n}=3$; Phase III: $n=14$ ), and a reduction and sometimes exclusion of certain tool types (type $\mathrm{F}$ and $\mathrm{G}$ points, type $B$ needles and spoon handles are all absent during the Chalcolithic). During this phase, raw material was readily available and construction techniques followed known patterns. Most of the developments beginning in Phase III continue into Phase II.

\section{Phase II (Middle Chalcolithic 4500-4300 cal BC)}

Fifty-three worked bone and antler objects were recovered from this phase. Although pointed tools remain the most recorded group $(\mathrm{n}=21)$, polishing tools are a close second $(\mathrm{n}=15)$. Points dominate $(n=13)$ and are defined by their homogeneity, with the majority type $A(n=8)$. Needles occur in rela-
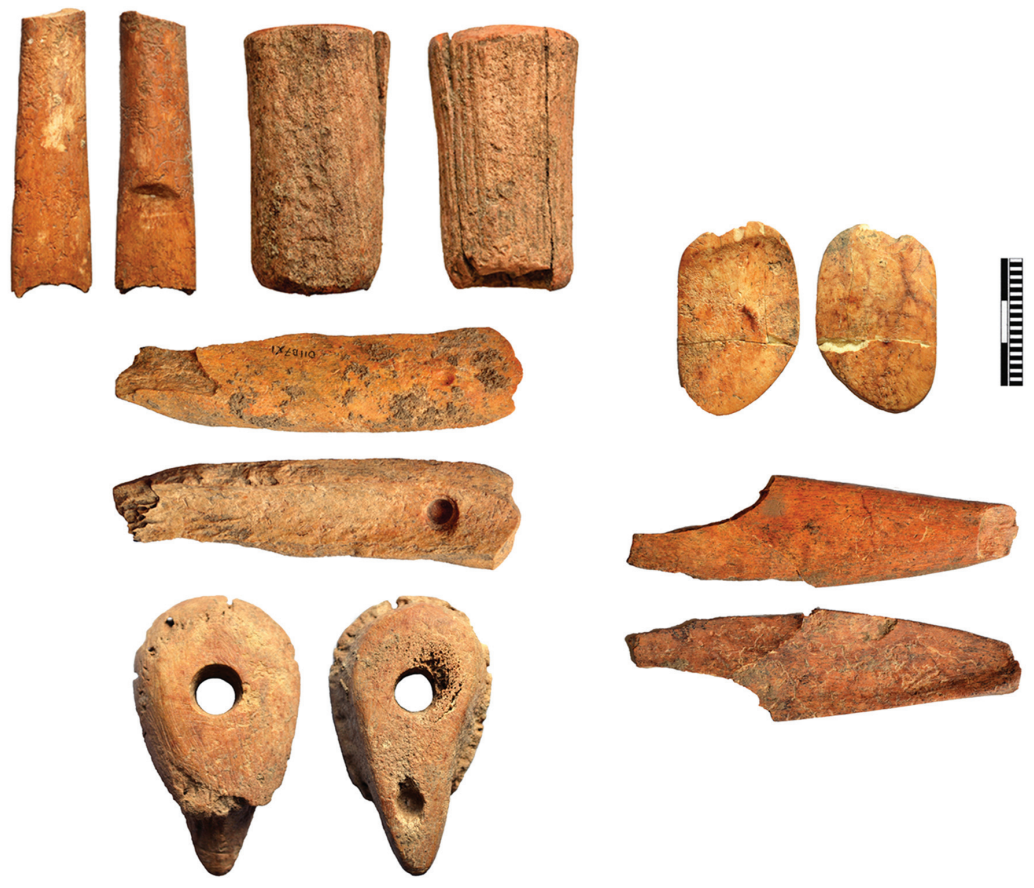

Fig. 8. Ŭ̈urlu other tools. Left to right: component/Composite elements type A-handle (BB20-21B29x2); component/composite elements type B- shaft (P6B5x6); perforated object (P5B68x1); preform (011B7x1); utensil type A-spoon (DD20B8x1); utensil type B- spatulaspoon (CC21B26x2) (designed by J. W. Paul).

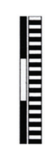

tively smaller numbers during this period $(\mathrm{n}=3)$, with the inclusion of one type $B$ needle, with a perforated base, and two type A needles. The two type A needles appear rudimentary when compared to their earlier counterparts, although they retain their slender shaft and appearance. No cutting tools were found during Phase II. This may reflect the use of other tool groups to replace these larger and more robust bone tools. 14 smoothers are disproportionately divided between type A $(n=13)$ and type B ( $=1$ ) and are seen as crude variations on previous forms, with some displaying unworked distal epiphyses, while others have had their bases removed entirely. Undefined objects dramatically increase in this phase, $28 \%$ of the overall Phase II collection, with higher occurrences revealing a noticeable amendment to tool construction methodology. This is not to say skill levels dropped without exception. 011B7x1 (Fig. 11) shows evidence of perforation on one aspect, made by a drill-like instrument. The second aspect has been indented for use as a guide. When considered together with the type B needle, it becomes clear expert craftspeople were still operating on bone and antler, just not to the same degree as in previous phases.

Almost all Phase II material comes from the western side of the site (in trenches 011, OP11, P5, and P6), with only two objects from the eastern side (trenches BB14 and BB15). Unit B4 in trench OP11 is associated with Building 1 , a rectangular building $7 \times 9 \mathrm{~m}$, and included two worked bone objects, with a pestle, spindle whorl, and worked sea-shell on its floor. Spindle whorls, an object used for textile manufacture that has not occurred frequently up to this point, are also found with worked bone items in trenches $\mathrm{P} 6$ (unit B2) and P5 (unit B2). Their increased presence could indicate an on-site shift in textile manufacture. Regularity in tool form also seems apparent. For instance, unit $\mathrm{B} 2$ in trench $\mathrm{P} 6$ contained three large, open-shafted smoothers, all with a slanted tip and similar use-wear characteristics from striation patterns.

Phase II worked bone was influenced particularly by the preced- 
ing Chalcolithic Phase III period. Most of the type tendencies from the Neolithic had by now changed, with the exception of pointed tools. There was also a reduction in quality, but construction skill for certain objects remained consistent. By the conclusion of Phase II, worked bone tools at Uğurlu were being associated with a wider variety of objects than ever before.

\section{Discussion}

\section{Uğurlu worked bone and antler: a local per- spective}

The worked bone and antler at Uğurlu can be described as an adaptable assemblage, adjusted to suit the needs of a society which sourced, modified, and used their tools to create essential items for daily use (Tab. 4). These tools were not created and used in isolation, but were rather connected to the larger material collection. Much of the raw material used to create these tools came from medium-sized animal bones $(\mathrm{n}=116)$, which included sheep and goats. Access to animals was the first step in the manufacturing sequence at Uğurlu. A select number of animals would have been chosen for the initial journey, with small- and medium-sized ones (sheep, goat, and pigs) favoured due to limited space on searafts (Camps 1986.23; Broodbank, Strasser 1991. 240-241; Simmons 2014.77). Animal selection had a direct influence on bone tool manufacturing, as the choice of animal would have been initially restricted. This is reflected in the assemblage, with tools made from large animal bones barely noticeable in the earliest periods (Phase V: $n=1$ ) and steadily growing as time passed (Phase IV: $n=12$ ). Animals were not slaughtered specifically for the production of tools; rather, they were butchered only when every available resource was depleted, including breeding with other animals to increase the size of the herd and extracting any meat or marrow. Due to size regulation, $70 \%$ of tools produced during the Neolithic from a known origin came from medium- sized animals such as sheep and goat. Fish hooks are also recorded in this early assemblage. Fish hooks and other fishing-related items such as nets would have been of great use on an island site, as fish and other molluscs could have supplemented a rather restricted diet (Powell 1996.104-105). As a result, the emergence of bone fish hooks around $6500 \mathrm{cal} \mathrm{BC}$ reflects an early adaptation of material culture not entirely land-based.

Moving into the Late Neolithic period (5900-5600 cal BC) at the site, Phase IV sees an increase in polishing tools. Moreover, decorated points (type F) are manufactured for the first time. Decorated points make a relatively short appearance in the cultural record, and then completely disappear by the end of Phase IV. These incisions were probably purely decorative. The introduction of artistic embellishments on functional tools thus shows a shift towards increased time allotment and greater manufacturing skill. Two clothing bone hooks also contain markings. One decorated with anthropomorphised features might be interpreted as a figurine, while the other contains a bird motif, which suggests some sort of symbolic importance.

Phase IV also witnessed a dramatic growth in the number of bone tools produced. With each object created, the operational chain is altered to provide optimal effectiveness for the user. For instance, the awl-shaped points (type $\mathrm{G}$ ) give the user greater room to manoeuvre when boring holes through dried animal hide. Consequently, the array of point types reflects an expansion of tool preparation, linked with greater accessibility of raw material or increased skill. Needles are not found in Phase V, but increase in frequency during Phase IV (Phase IV: $n=$ 12). They then decline drastically in number during the Chalcolithic (Phase III: $n=6$; Phase II: $n=3$ ). Given their shape, these needles may have been inserted into figurines found in contextually comparable locations, to represent a human form. Perhaps
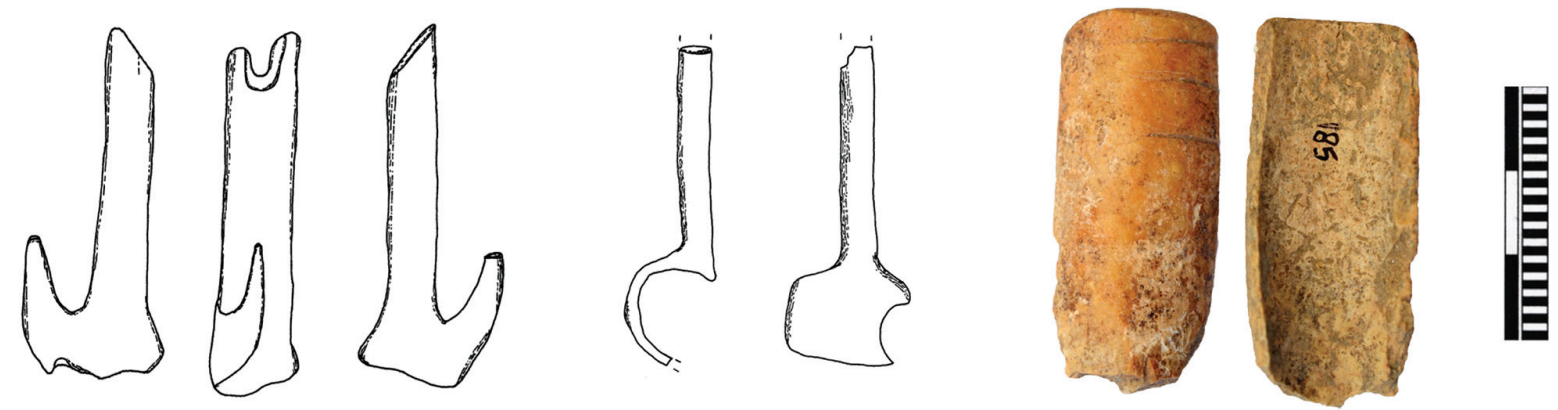

Fig. 9. Undefined tools. Left to right: Q6B10x2; OP11B8x10; P5B50xz3 (designed by B. Erdoğu and J. W. Paul). 

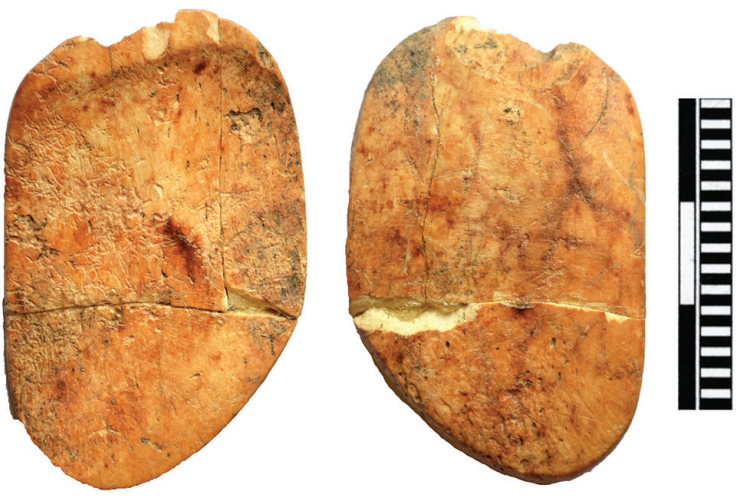

Fig. 10. DD20B8x1 (photo by J. W. Paul).

these needles also played a symbolic role, contributing to the notion that Gökçeada may have been a 'sacred landscape.' It is conceivable that the island was prominent during prehistory due to its visible position from the mainland and anthropomorphised natural features (Erdoğu 2003.7-22). These needles may have substituted the religious/social identity of the island (Erdoğ 2003.19). Supporting this claim is the fact that these needles were found inside yellow plastered storage pits. Objects found inside, or associated with, plaster pits are common across Anatolia during the Neolithic, protecting the items housed inside (Perlès 2005.275). However, plaster pits also seem to serve a ritual or religious function, with plaster used at prehistoric Anatolian sites in conjunction with ritual activity, particularly during moments of transition (Balter 2001.2278-2281; Hodder 2005. 10-11; Cessford, Near 2005.179). The apparent short-lived popularity of needle production may have been the result of raw material choice, as other materials, such as wood, may have been favoured during later phases.

Although spatula-spoons are found in Phase VI, relatively complete examples of spoon heads or handles are first seen in Phase V and IV. Spoons are common on mainland Anatolia and Thrace, with finely worked objects frequently found (Lichardus-Itten et al. 2006.88-89; Özdoğan 2013.182-187). Spoons may be linked with an original toolkit transported onto the island by mainland farming groups. These objects do not appear in the assemblage during the Chalcolithic, perhaps replaced again by raw material alternatives such as wood.

New procedures in the manufacturing sequence, seen in Phase IV, meant bone tools could be used with more force. Techniques such as the controlled burning of medium-sized animal bone tips during the final stage of manufacture solidified the tool's working end. This type of manufacturing sequence can be found on a number of items labelled gouges and chisels. Significant amounts of large animal long bones were also used to create gouges and chisels during the Neolithic (Phase V: $\mathrm{n}=0$; Phase IV: $\mathrm{n}=$ 6), resulting in two outcomes. First, bone tools made from large animal bones indicate an increased availability of large animals, or at least improved access to them. Second, the apparent willingness to try different manufacture methods suggests stability. If resources are scarce, or tools are needed for immediate use, time and experimentation give way to expediency and functionality. For example, tools deliberately burnt in a controlled setting emphasise a community relatively abundant in resources, with little time constraints to maintain production on an immediate basis.

From Phase IV onwards, greater numbers of unclassified objects began to emerge at Uğurlu (Phase IV = 9.9\%; Phase III $=15.3 \%$; Phase II $=28.3 \%$ ). This may have been a direct result of experimentation, as different manufacturing methods were used to enhance tool capability. Underscoring this was the development of raw material not previously used at Uğurlu to make bone tools. As well as the increased use of large animal bones, deer antler was used in greater quantities (Phase V: $n=1$; Phase IV: $n=7$; Phase III: $\mathrm{n}=11$ ). Bone tool production steadily changed and adapted from the Neolithic to the Chalcolithic. There was no abrupt change in types or groups. Rather,
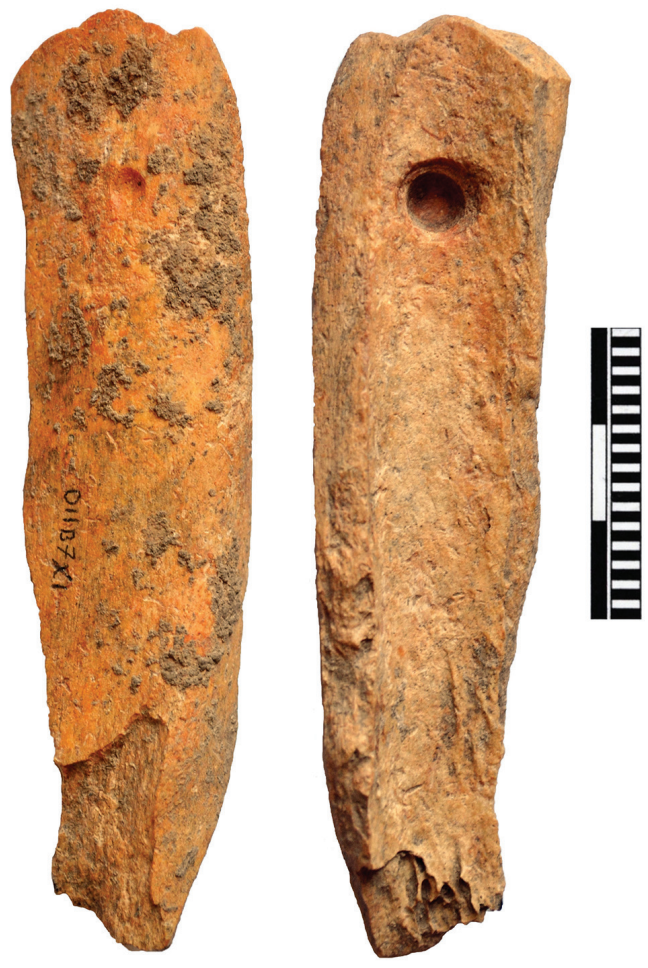

Fig. 11. 011B7x1 (photo by J. W. Paul). 


\begin{tabular}{|c|c|c|c|c|c|c|c|c|c|c|c|}
\hline \multirow[t]{2}{*}{ Group } & \multirow[t]{2}{*}{ Type } & \multicolumn{10}{|c|}{ Phase } \\
\hline & & VI & $\mathbf{V}$ & V-IV & IV & IV-III & III & II & surface & unknown & Total \\
\hline \multirow{6}{*}{$\begin{array}{l}\text { Pointed } \\
\text { tools }\end{array}$} & point & 1 & 11 & 11 & 63 & 9 & 63 & 13 & 7 & 13 & 191 \\
\hline & rounded point & - & 3 & - & 4 & 4 & 12 & 3 & 2 & 3 & 31 \\
\hline & bi-point & - & 1 & - & 1 & - & - & - & - & - & 2 \\
\hline & fish hook & - & - & 1 & 2 & - & 2 & - & - & 1 & 6 \\
\hline & needle & - & - & - & 12 & - & 6 & 3 & 1 & 1 & 23 \\
\hline & pin & - & 1 & - & 18 & 6 & 20 & 2 & - & - & 47 \\
\hline \multirow{4}{*}{$\begin{array}{l}\text { Cutting } \\
\text { tools }\end{array}$} & chisel & - & - & - & 3 & - & 1 & - & - & - & 4 \\
\hline & gouge & - & - & 1 & 3 & - & 3 & - & 1 & - & 8 \\
\hline & pick & - & - & - & - & - & 1 & - & - & - & 1 \\
\hline & puncher & - & - & - & - & - & - & - & - & 1 & 1 \\
\hline \multirow{2}{*}{$\begin{array}{l}\text { Polishing } \\
\text { Tools }\end{array}$} & smoother & - & 1 & 3 & 29 & 6 & 23 & 14 & 6 & 9 & 91 \\
\hline & spatula & 4 & 1 & 4 & 6 & 1 & 12 & 1 & 1 & - & 30 \\
\hline \multirow[t]{5}{*}{ Other } & $\begin{array}{l}\text { component/composite } \\
\text { elements }\end{array}$ & - & 1 & 1 & 1 & 1 & 3 & 1 & 1 & 1 & 10 \\
\hline & perforated object & - & - & - & - & - & 1 & - & - & 1 & 2 \\
\hline & preform & - & - & 1 & - & 1 & 1 & 1 & - & - & 4 \\
\hline & utensil & $\begin{array}{l}- \\
-\end{array}$ & - & - & 3 & - & 1 & - & - & - & 4 \\
\hline & undefined & - & 4 & 1 & 16 & 6 & 27 & 15 & 5 & 5 & 79 \\
\hline Total & & 5 & 23 & 23 & 161 & 34 & 176 & 53 & 24 & 35 & 534 \\
\hline
\end{tabular}

Tab. 4. Ŭ̆urlu worked bone and antler contextual distribution.

certain production characteristics that began around 5500 cal BC continued during the Chalcolithic Phase III period.

Many of the pointed tools recorded in Phase IV carry over to Phase III, including points, rounded points, needles, and pins. Despite this, regularity and production contrasts with their Neolithic counterparts, as sub-types seem to be favoured. Most of the Chalcolithic Phase III points (67\%) are broken at the shaft (type A), with round-based versions (type D) also well represented (16\%). There is no evidence of decorated (type F) or awl-shaped (type G) points during the Chalcolithic Phase III or II. An apparent maximisation of broken points may reflect an overall expanded manufacturing output, as many of these tools are found in pits and pit levels, rather than floor levels. Increased numbers of disposed items might correlate with amplified production and use, as tools were discarded in greater numbers. Rounded points made from bone and antler expand exponentially when compared to previous phases (Phase IV: $2.7 \%$; Phase III: $8.1 \%)$. During Phase IV, spatulas are scarce in the overall record and evenly distributed across two sub-types (type A: $n=3$; type $B$ : $n=$ 3). In contrast, during Phase III, they double in number, and almost completely conform to type A (type $A: n=10$; type $B: n=2$ ). Greater frequency of spatulas during Phase III (8.1\%) when compared to Phase IV (4.1\%) may also be linked to expanded pottery production, as these tools were primarily used to smooth ceramics during the moulding stage.
Choice of raw material also develops during the Chalcolithic. For instance, antler production, which seems to begin at the end of the Neolithic Phase IV $(6000 / 5900 \mathrm{cal}$ BC), grows in subsequent phases. This material was used to create rounded points (type B), shafts, and a pick. Not every tool type grew in frequency, however. Most notably, needles (Phase IV: $8.3 \%$; Phase III: 4\%) and utensils (Phase IV: 2.1\%; Phase III: $0.7 \%$ ) reduce in volume when compared to Phase IV. Type A needles, possibly associated with ritual activity during the Neolithic, were still used, but halved in number (Phase IV: $n=12$; Phase III: $n=6$ ).

When compared to previous phases, Phase II bone objects seem to be crudely made. A foremost sense of functionality over any visual appeal pervades the collection. Unclassified material is much larger when compared to earlier phases, with a ratio of almost 2:1 in terms of classified to unclassified material. In comparison, Phase III is roughly 5:1, while Phase IV is even higher. The number of smoothers also dramatically rises in Phase II (36.8\% of the typed assemblage). In fact, they outnumber points (34.2\%), a tool type consistently favoured throughout the site's history. They are smaller (mean length of $68.6 \mathrm{~mm}$; SD 20.4) when compared to Phase III smoothers (mean length of $79.1 \mathrm{~mm}$; SD 32.1). The adaption of textile manufacture during this phase, coupled with the increase of spindle whorls, might explain the lower frequency of points. Additionally, other material types, such as copper, may have been used, although limited evidence has been discovered to support this claim. 
The modification of tool types, and the context in which they were discarded, provides insight into shifting site processes. For example, the constant reliance of pointed tools highlights confidence in the sourcing of certain raw material, including sheep and goat metapodial bones. Likewise, the disappearance of spoons after the Neolithic indicates a shift perhaps to a more localised toolkit. Needles, with their distinctive bases, coupled with a different ceramic technique, also emphasises a shift towards a localised material culture. Thus, an overall initial impression of the Uğurlu worked bone material is stability at a tool group level, while variation and adaptions occur at a tool type level.

\section{Uğurlu worked bone and antler: a regional perspective}

The spread of Neolithisation to the corners of Anatolia is seen as a complex issue not easily solved by a simplistic model of migration (Colledge et al. 2004. 35; Tomkins 2004.56; Özdoğan 2011.415-430; Budja 2013.47; Düring 2013.75-100; Lichter 2002. 161-169; Pinhasi et al. 2005.2220-2228; Thissen 1999.29-39). In this regard, a web of interconnected strategies should be determined on an individual basis, with an emphasis on certain 'push' and 'pull' factors (Anthony 1990.895; 1997.22).

Despite Uğurlu's distance from the mainland (approx. $12 \mathrm{~km}$ during prehistory), common regional material was evident at the site. Certain ceramic types at Uğurlu, such as Impresso ware, were common on the Anatolian west coast (Özdoğan 2010. 886). Additionally, white-on-red painted ware, found in Phase IV at Uğurlu, was widespread north of the island, originating from Karanovo (Erdoğu 2014. 160; Marinova 2007.93). Obsidian from Melos is also evident at Uğurlu, and was widespread in the region, with examples seen to the west and east ( $E r$ doğu 2014.161; Sampson 1998.20; Takaoğlu 2013. 36; Miliç 2014).

The extensive use of worked bone is also evident in this region, with certain common tool groups common to both Uğurlu and contemporary sites. Pointed tools were the predominant tool group at most sites in the region, with points (or awls, as they are also labelled) the most common type. Points were the most common type at Ulucak, Ilipinar, Barcin Höyük, Dikili Tash, and Makri all have a predominance of points in their assemblages (Marinelli 1995. 124; Dekker 2014.64-65; Gerritsen et al. 2013.93112; Séfériadés 1992.102-104; Stratouli 1998.3640). The most common sub-type seems to be the
Uğurlu type B point, with morphologically similar sub-types evident at Ulucak (type B), Illıpınar (type A), Dikili Tash (type IIIB), the Cave of Cyclops (type B), and Karanovo (type A). The large amount of pointed tools found across the region is the result of several factors, including the relatively simple set of manufacturing steps needed to produce points, a wide selection of raw material to draw upon during construction, and the ease of breakage. Smoothers at Uğurlu also find regional parallels, for example at Ilıpınar, Dikili Tash, and Karanovo, although they are often labelled as chisels (Marinelli 1995.126; Séfériadés 1992.100-101; Höglinger 1997.161).

However, when investigating regionally comparative worked bone assemblages, certain characteristic tool types become evident. For Uğurlu, this is the type A needle, not seen in collections across the region, except for a wooden parallel at Yenikapı (Kizltan, Polat 2013.123). For sites in Anatolia, Ulucak Höyük is characterised by its increased production and use of larger animal bones, while Ilipinar has a well-represented collection of spoons, toys, and figurines (Marinelli 1995.121-143). Barcin Höyük, Pendik, Fikirtepe, Hoca Çeşme, and Aşağı Pınar all have high-quality bone spoons in their assemblages. These are well made, richly decorated items. Northwest of the island, Dikili Tash is reliant on deer antler as a raw material source, more so than any other in the region. The assemblage at Makri is defined by the absence of items such as spoons, fish hooks, pendants, and spatulas (Stratouli 1998.36-40). Karanovo, emerging from the Anatolian tradition, contains a large section of well-crafted spoons, also common to the Thrace area (Höglinger 1997.157-159). Sites in the region, therefore, have certain unique worked bone tool types that are not always widespread or shared between sites. As a result, not all types seen at Uğurlu are shared with other sites.

Overall, the Uğurlu assemblage can therefore be seen as one that shares common regional tool groups, while also displaying localised tool types (for example, type A needles). Regarding the Neolithisation of the island, a land-based agricultural society relied on domestic animals, grains, and a toolkit largely made up of types consistent with other mainland cultures. As time passed, however, certain localised traditions took effect, most evident in the change of ceramics. This is also reflected in the worked bone assemblage, for instance with the decrease in bone spoons, highlighting shifting manufacturing practices. Although Uğurlu borrows various elements from the Anatolian tradition, bone spoons (and the associated handles) 
are rare and were produced only during the Neolithic (Phase V: $n=2$; Phase IV: $n=4$ ). The decrease in the number of utensils in Chalcolithic Phase III at Uğurlu does reflect larger trends north and west of the island. The lack of spoons is synonymous with sites located in modern Greece during the same period (Perlès 2005.278). Sites in Anatolia (particularly Thrace) had a continual use and manufacture of bone spoons during this time, which makes the lack of widespread transfer to the Aegean prominent in the material record.

Thus, it is clear that the worked bone and antler collection at Uğurlu was entirely consistent with nearby sites, its dynamic assemblage working within a global tradition that, like other sites investigated, had its own distinctive local traditions.

\section{Conclusion}

When Uğurlu was first settled in the 7th millennium cal BC, bone tool production was already underway, as it was an essential component of the prehistoric toolkit. Throughout the Neolithic and Chalcolithic, as the site grew, so too did bone tool manufacture, incorporating a wider variety of animal bone and antler during subsequent phases. The worked bone assemblage did not exist in isolation, but was rather one element assisting and enhancing the Neolithic way of life. As a result, these bone objects were used to sew animal hide into shoes and bags, mould clay into pots for cooking and storage, secure fish to a line, and conceivably assist in ritual performance.

Future studies regarding the Uğurlu worked bone collection will focus on further use-wear analysis to support functional assignment. Further investigation of analogous tool types with those found at Uğurlu, such as type A needles and decorated points, would also be worthwhile as part of a larger comparative analysis including sites to the north and east.

In sum, stability defines the Uğurlu worked bone assemblage, with their production, use, and discard remaining constant over roughly 2000 years. This collection played an extremely important supportive role in the establishment and maintenance of a community located at a geographic and cultural crossroads.

Jarrad W. Paul wishes to acknowledge the following support: Australia Postgraduate Award, Jessie Webb Scholarship, Lizette Bentwitch Scholarship, and the Graduate Research in Arts Travel Scheme (University of Melbourne, Australia). The Uğurlu Excavation project is supported by The Turkish Ministry of Culture and Tourism and University of Thrace.

\section{References}

Anthony D. W. 1990. Migration in Archaeology: The baby and the bathwater. American Anthropologist 92(4): 895914.

1997. Prehistoric migration as social process. In J. Chapman, H. Hamerow (eds.), Migrations and Invasions in Archaeological Explanation. Archaeopress. Oxford: 21-32.

Azeri H. 2015. The Evaluation of the Bone Assemblage of Aşağı Pınar Mound's Chalcolithic Period. Unpublished MA thesis. Istanbul University. Istanbul.

Balter M. 2001. Did Plaster Hold Neolithic Society Together? Science 14(294): 2278- 2281.

Bradfield J. 2015. Investigating the potential of micro-focus computed tomography in the study of ancient bone tool function: results from actualistic experiments. Journal of Archaeological Science 40: 2606-2613.

Broodbank C., Strasser T. F. 1991. Migrant farmers and the Neolithic colonisation of Crete. Antiquity 65(247): 233-245.

Budja M. 2013. Neolithic pots and potters in Europe: the end of 'demic diffusion' migratory model. Documenta Praehistorica 40: 39-55.

Camps G. 1986. The Young Sheep and the Sea: Early Navigation in the Mediterranean. Diogenes 34: 19-45.

Camps-Fabrer H. 1966. Matière et art mobilier dans la préhistoire Nord-Africaine et Saharienne. Arts et Métiers Graphiques. Paris. 
Cessford C., Near J. 2005. Fire, Burning and Pyrotechnology. In I. Hodder (ed.), Catalhöyük perspectives: themes from the 1995-1999 seasons. McDonald Institute for Archaeological Research/British Institute of Archaeology at Ankara. Cambridge: 171-182.

Çevik Ö. 2012. Ulucak Höyük 2009-2011 Yılı Kazı Çalışmaları. Kazı Sonuçları Toplantısı 34: 143-158.

Choyke A. M. 2007. Objects for a Lifetime- Tools for a Season: the bone tools from Ecsegfalva 23. In A. Whittle (ed.), The Early Neolithic on the Great Hungarian Plain: Investigations of the Körös culture site of Ecsegfalva 23, County Békés. Archaeological Institute of the Hungarian Academy of Sciences. Budapest: 641-665.

Christidou R. 2005. Aspects of bone exploitation in the Neolithic sites of Eastern Macedonia, Greece. In H. Luik, A. M. Choyke, C. E. Batey and L. Lõugas (eds.), From Hooves to Horns, from Mollusc to Mammoth - Manufacture and Use of Bone Artefacts from Prehistoric Times to the Present. Teaduste Akadeemia Kirjastus. Tallinn: 91-104.

Çilingiroğlu A., Derin Z., Abay E., Sağlamtimur H. and Kayan I. 2004. Ulucak Höyük Excavations Conducted Between 1995 and 2002. Peeters. Louvain.

Colledge, S., Conolly J. and Shennan S. 2004. Archaeobotanical Evidence for the Spread of Farming in the Eastern Mediterranean. Current Anthropology 45: 35-58.

Dekker K. 2014. What tools can tell. The Bone Tools of Barcin Höyük. Unpublished MA thesis. Free University of Amsterdam. Netherlands.

Derin Z. 2012. Yeşilova Höyük. In M. Özdoğan, N. Başgelen and P. Kuniholm (eds.), The Neolithic In Turkey. Volume 4. Western Turkey. Archaeology and Art Publications. Istanbul: 177-195.

D'Errico F., Giacobini G. and Puech P.-F. 1984. Varnish Replicas: A new method for the study of worked bone surfaces. Ossa International Journal of Skeletal Research 9(11): 29-51.

Düring B. 2013. Breaking the Bond: Investigating the Neolithic Expansion in Asia Minor in the Seventh Millennium BC. Journal of World Prehistory 26: 75-100.

Erdalkıran B. 2017. Barçın Höyük 2015 Yılı Kemik Aletlerinin Ön Raporu. Arkeometri Sonuçları Toplantısı 32: 235-249.

Erdoğu B. 2003. Visualising Neolithic Landscape: the early settled communities in Western Anatolia and Eastern Aegean Islands. European Journal of Archaeology 6(1): $7-23$.
2014. Gökçeada Uğurlu Archaeological Project: A Preliminary Report from the 2011-2013 Field Seasons. Anatolica 40: 157-178.

2016. The Neolithic landscape and settlement of the Island of Gökçeada (Imbros, Turkey). In M. Ghilardi (ed.), Géoarchéologie des îles de Méditerranée. Centre National de la Recherche Scientifique. Paris: 89-94.

Gerritsen F., Özbel R. and Thissen L. 2013. Barcın Höyük: The beginnings of Farming in the Marmara Region. In M. Özdoğan, N. Başgelen and P. Kuniholm (eds.), The Neolithic in Turkey. Volume 5. Northwestern Turkey and Istanbul. Archaeology and Art Publications. Istanbul: 93112.

Goodarzi-Tabrizi S. 1999. The Worked Bone Remains of Hallan Cemi Tepesi, an Early Neolithic Site in Southeastern Turkey. Unpublished PhD thesis. University of California. Berkley.

Griffitts J. L. 2011. Use wear analysis on Catalhoyuk bone tools. In S. Farid (ed.), Catalhöyük 2011 Archive Report. Catalhöyük Research Project: 52-66. http://www.catalho yuk.com/archive_reports/2011.

Hodder I. 2005. Changing entanglements and temporalities. In I. Hodder (ed.), Changing materialities at Catalhöyük: reports from the 1995-99 seasons. McDonald Institute for Archaeological Research/British Institute of Archaeology at Ankara. Cambridge: 1-22.

Höglinger P. 1997. Neolithisches Bein- und Geweigherät. In S. Hiller, V. Nikolov (eds.), Karanovo I.1, Die Ausgrabungen im Südsektor 1984-1992. Verlag Ferdinand Berger \& Sohne. Salzburg and Sofia: 157-196.

Karul N., Avc1 M. B. 2011. Neolithic Communities in the Eastern Marmara Region: Aktopralı. Anatolica 37: 1-15.

Kızıltan Z., Polat M. A. 2013. The Neolithic at Yenikapı. In M. Özdoğan, N. Başgelen and P. Kuniholm (eds.), The Neolithic in Turkey. Volume 5. Northwestern Turkey and Istanbul. Archaeology and Art Publications. Istanbul: 113165 .

Legrand A., Sidéra I. 2007. Methods, Means, and Results when Studying European Bone Industries. In C. Gates StPierre, R. Walker (eds.), Bones as Tools: Current Methods and Intepretations in Worked Bone Studies. Archaeopress. Oxford: 67-80.

LeMoine G. M. 1997. Use Wear Analysis on Bone and Antler Tools of the Mackenzie Inuit. Archaeopress. 0xford.

Leshtakov K., Todorava N., Petrova V., Zlateva-Uzunova R., Özbek O., Popova T., Spassov N. and Iliev N. 2007. Preli- 
minary report on the salvage archaeological excavations at the early Neolithic site Yabalkovo in the Maritsa Valley, 2000-2005 field seasons. Anatolica 33: 185-234.

Lichardus-Itten M., Demoule J-P., Pernicheva L., GrebskaKulova M. and Kulov I. 2006. Kovačevo, an Early Neolithic site in South-West Bulgaria and its importance for European Neolithisation. In I. Gatsov, H. Schwarzberg (eds.), Aegean - Marmara - Black Sea: the Present State of research on the Early Neolithic. Beier and Beran. Langenweissbach: 83-94.

Lichter C. 2002. Central Western Anatolia - a key region in the Neolithisation of Europe. In F. Gérard, L. Thissen (eds.), The Neolithic of Central Anatolia: internal developments and external relations during the 9th-6 $\sigma^{\text {th }}$ millennia cal. BC. Ege Yayınları. Istanbul: 161-169.

Mărgărit M. 2017. Spatulas and braded astragalus: Two types of tools used to process ceramics? Examples from the Romanian prehistory. Quaternary International 438 : 201-211.

Marinelli M. 1995. The bone artifacts of Ilipinar. In J. Roodenberg (ed.), The Ilipinar Excavation I. Five Seasons of Fieldwork in Northwestern Anatolia, 1987-91. Nederlands Historisch-Archaeologisch Instituut te Istanbul. Leiden: 121-142.

Marinova E. 2007. Archaeobotanical data from the early Neolithic of Bulgaria. In S. Colledge, J. Conolly (eds.), The Origins and Spread of Domestic Plants in southwest Asia and Europe Left Coast Press. Walnut Creek: 93-109.

Milić M. 2014. PXRF characterisation of obsidian from central Anatolia, the Aegean and central Europe. Journal of Archaeological Science 41: 285-296.

Özdoğan M. 2001. Yarımburgaz Cave Excavations. In 0. Belli (ed.), Istanbul University's Contributions to Archaeology in Turkey (1932-2000). Istanbul University Rectorate Research Fund. Istanbul: 8-11.

2010. Westward expansion of the Neolithic way of life: sorting the Neolithic package into distinct packages". In P. Matthiae, F. Pinnock, L. Nigro and N. Marchetti (eds.), ICAANE 6, Proceedings of the $6^{\text {th }}$ International Congress of the Archaeology of the Ancient Near East. Volume 1. Near Eastern Archaeology in the Past, Present and Future. Harrassowitz Verlag. Wiesbaden: 883-893.

2011. Archaeological Evidence on the Westward Expansion of Farming Communities from Eastern Anatolia to the Aegean and the Balkans. Current Anthropology 52 (4): 415-430.

2013. Neolithic Sites in the Marmara Region: Fikirtepe, Pendik, Yarımburgaz, Toptepe, Hoca Çeşme, and Aşağı
Pinar. In M. Özdoğan, N. Başgelen and P. Kuniholm (eds.), The Neolithic in Turkey. Volume 5. Northwestern Turkey and Istanbul. Archaeology and Art Publications. Istanbul: 167-269.

Perlès C. 2005. From the Near East to Greece: Let's reverse the focus Cultural elements that didn't transfer. In C. Lichter (ed.), How did farming reach Europe? Anatolian-European relations from the Second half of the $7^{\text {th }}$ through the first half of the $6^{\text {th }}$ millennium cal. BC. Ege Yayınları. Istanbul: 275-290.

Pinhasi R., Fort J. and Ammerman A. J. 2005. Tracing the Origin and Spread of Agriculture in Europe. PLOS Biology 3(12): 2220-2228.

Powell J. 1996. Fishing in the Prehistoric Aegean. Paul Åströms Förlag. Jonsered.

Russell N. 2005. Çatalhöyük Worked Bone. In I. Hodder (ed.), Changing materialities at Catalhöyük: reports from the 1995-99 seasons. British Institute at Ankara. London: 339-369.

Sağlamtimur H. 2012. The Neolithic Settlement of Ege Gübre. In M. Özdoğan, N. Başgelen and P. Kuniholm (eds.), The Neolithic In Turkey. Volume 4. Western Turkey. Archaeology and Art Publications. Istanbul: 197-225.

Sampson A. 1998. The Neolithic and Mesolithic Occupation of the Cave of Cyclops, Youra, Alonnessos, Greece. The Annual of the British School at Athens 93: 1-22.

Schibler J. 1980. Osteologische Untersuchung der cortaillodzeitlichen Knochenartefakte. Die neolithischen Ufersiedlungen von Twann. Volume 8. Staatlicher Lehrmittelverlag. Bern.

Séfériadés M. 1992. Bone tool report. In R. Treuil (ed.), Dikili Tash, village préhistorique de Macédoine orientale, I. Fouilles de Jean Deshayes (1961-1975). Volume 1. Bulletin de Correspondance Hellénique Supplément XXIV. Athens: 99-112.

Semenov S. A. 1964. Prehistoric Technology: an Experimental Study of the oldest Tools and Artefacts from traces of Manufacture and Wear. Barnes and Noble. New York.

Sidéra I. 2013. Manufacturing Bone Tools: The Example of Kovačevo. In N. Miladinović-Radmilović, S. Vitezović (eds.), Bioarheologija Na Balkanu: Bilans i perspektive. Srpsko arheološko društvo. Sremska Mitrovica. Beograd: 173178.

Simmons A. H. 2014. Stone Age Sailors: Paleolithic Seafaring in the Mediterranean. Left Coast Press. Walnut Creek. 
Spangenberg J. E., Ferrer M., Jacomet S., Bleicher N. and Schibler J. 2014. Molecular and isotopic characterisation of lipids staining bone and antler tools in the Late Neolithic settlement, Zurich Opera Parking, Switzerland. Organic Geochemistry 69: 11-25.

Stratouli G. 1998. Bone artefacts from Makri. In N. Efstratiou, M. P. Fumanal, C. Ferrer, D. Urem Kotsos, A. Curci, A. Tagliacozzo, G. Stratouli, S. M. Valmomti, M. Ntinou, E. Badal, M. Madella and K. Skourtopoulou (eds.), Excavations at the Neolithic settlement of Makri, Thrace, Greece (1988-1996): A preliminary report. Papeles del Laboratorio de Arqueología de Valencia. Saguntum: 36-40.

Takaoğlu T. 2013. Coşkuntepe: A Neolithic Village in the Coastal Troad. In M. Özdoğan, N. Başgelen and P. Kuniholm (eds.), The Neolithic in Turkey. Volume 5. Northwestern Turkey and Istanbul. Archaeology and Art Publications. Istanbul: 35-43.

Thissen L. 1999. Trajectories towards the Neolithisation of NW Turkey. Documenta Praehistorica 26: 29-39.
Tomkins P. 2004. Filling in the 'Neolithic Background': Social Life and Social Transformation in the Aegean before the Bronze Age. In J. C. Barrett, P. Halstead (eds.), The Emergence of Civilisation Revisited. Oxbow Books. Oxford: 38-63.

Vitezović S. 2011. The Neolithic Bone Industry from Drenovac, Serbia. In J. Baron, B. Kufel-Diakowska (eds.), Written in Bones: Studies on technological and social contexts of past faunal skeletal remains. Institute of Archaeology University of Wrocław. Wrocław: 117-136.

Zidarov P. 2008. Pointed bone tools from Măgura Gorgana. In S. Hansen, M. Toderas, A. Reingruber, I. Gatsov, F. Klimscha, P. Nedelcheva, R. Neef, M. Prange, T. D. Price, J. Wahl, B. Weninger, H. Wrobel, J. Wunderlich and P. Zidarov (eds.), Der kupferzeitliche Siedlungshügel Măgura Gorgana bei Pietrele in der Walachei. Ergebnisse der Ausgrabungen im Sommer 2007. Eurasia Antiqua 14. V. Zabern. Mainz: 57-62.

\section{back to contents}

